\title{
Reward Governance Case
}

\author{
by Rolf Dubs \\ (Switzerland)
}

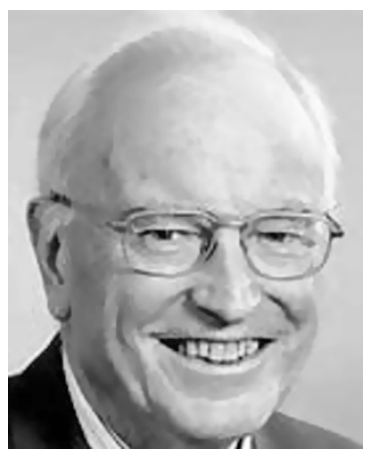

University of St. Gallen

International Center for Corporate Governance

At present a lot of writing takes place about sustainable management (ESG, environmental, social and governance issues). But many members of the supervisory board still have a hard time to deal with it.

The supervisory board of an enterprise in the food sector with approx. 1500 employees was represented by president and 6 members, of whom a woman had the following agenda item on their spring meeting - annual financial statement:

4. Acceptation of the annual financial statement:

4.1 Discuss the financial report and the management letters from the auditing firm.

4.2 Request to the general meeting about the distribution of profits.

4.3 Discuss the distribution of bonuses, proposed by the corporate management.

\section{Target: Resolution}

Turnover and profit were way beyond the conservative budgets of the previous year.

Whereas paragraphs 4.1 and 4.2 did not provoke any discussions, paragraph 4.3 led to a lengthy and fierce discussion which evolved as follows: The HR manager

Reference: Dubs, R. (2015). Normatives Management (normative management). A contribution to sustainable corporate governance (3rd edition). Bern: Haupt. 
explained the process of officialized bonus determination and substantiated the proposed solution. Contrary to the processing of this topic in previous years, Carl Müller demanded the word and asked:

How many of the 1500 employees will receive a bonus this year?

After an instant of hesitation the HR manager announced that 60 cadre employees, including corporate management, would benefit thereof. Following that, Carl Müller proposed a motion to comprehensively revise the bonus regulations for the years to come and if good profits occur to provide bonuses for all 1500 employees. He argued as follows:

\footnotetext{
We have to perceive social responsibility, enterprises should — within their means-contribute to a reasonable social compensation-In other words perceive social responsibility and provide fair potential earnings for all employees.

This means to concede bonuses to all employees, then they all contributed to the success. Furthermore the existing understanding of bonuses fosters the society separation in elitewhich sets itself progressively apart-and the simple folks; this is on the long run a dangerous trend. For this reason the bonus policy has to be scrutinised.

We would be badly mistaken to believe that we would have done enough for sustainable governance with our environmental measures and thoughtful sponsoring.
}

Two of the executive directors reacted quite fiercely: One meant that the enterprise would already invest substantially for a good working atmosphere, which would contribute much more significantly to success than "a little more money for the employees". The second relegated to the legally required compliance with minimum wages, which the company-in spite of cost trends-since years would fulfil in an exemplary manner. For this reason our company perceives the social responsibility sufficiently clear.

Which opinion would you represent on the Board of Directors and what would be your reason?

And how would you vote on the application?

\section{What Happened in Reality and How Did the Vote Turn Out?}

- The motion was passed unanimously. It was most supported by the vote of a board member who unexpectedly asked how the individual members of the Board of Directors would finance the non-resident study of a child, with a minimum wage of $\mathrm{CHF}$ 4000. This remark led to some embarrassment for individual members. Another member was surprised because he had never dealt with such a question at a board meeting.

- The corporate management immediately started work on the new regulations. In doing so a challenging problem occurred: How can incentive pay be distinguished 
from bonuses - particularly in case of employees without executive functionsas undifferentiated compensations would lead to social injustice between "highly performing employees" and "minimalists".

- The following options were discussed amongst the Board of Directors:

1. General elimination of the bonuses, as it is scientifically proven that bonuses are not a significant motivational factor.

2. A general, appropriate increase of cadre wages, because a wage differentiation by cadre level is taken for granted. The bonuses are distributed proportionally to all working groups of all levels as a total amount—with the task to decide on the distribution to their group members autonomously. In this way, the "high performers" can receive a little more, whereas the "minimalists" in the following year rather will strive for better performance, as attempts with this wage plan have already proofed.

The decision is still pending.

\section{What Can We Learn from This Case?}

1. Procedural: One should refrain from spontaneous applications to the board meeting, unless one is also willing and/or able to present feasible ideas for implementation.

2. In view of the many problems and conflicts of aims in today's corporate governance and its implications for corporate and social development, normative management (sustainable corporate governance) must be incorporated into strategic thinking in boards of directors.

3. Unlike many board members, corporate management is now increasingly interested in normative management, but does not dare to implement it in because many members of supervisory boards are not yet involved in it and/or they fear resistance of shareholders. Without the role model of the Board of Directors, the combination of strategic and normative management often fails.

4. The consideration of normative management, which-besides environmental issues and sponsoring - must also include social issues and governance, should not be dismissed as a "social visionariness", but its implementation should continue to give due weight to the economic issues. Honest economic constraints remain a limitation of many normative management ideas. However, a paradigm shift should be achieved, which I no longer focus on the short term, ruthless principle of profit maximization but on the goal of a profit under constraints. 
Open Access This chapter is licensed under the terms of the Creative Commons Attribution 4.0 International License (http://creativecommons.org/licenses/by/4.0/), which permits use, sharing, adaptation, distribution and reproduction in any medium or format, as long as you give appropriate credit to the original author(s) and the source, provide a link to the Creative Commons licence and indicate if changes were made.

The images or other third party material in this chapter are included in the chapter's Creative Commons licence, unless indicated otherwise in a credit line to the material. If material is not included in the chapter's Creative Commons licence and your intended use is not permitted by statutory regulation or exceeds the permitted use, you will need to obtain permission directly from the copyright holder.

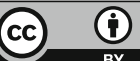

